\title{
UTILIZING WHATSAPP APPLICATION FOR TEACHING INTEGRATED ENGLISH (A CASE STUDY AT UNIVERSITY OF TECHNOLOGY YOGYAKARTA)
}

\section{Septi Riana Dewi}

Universitas Teknologi Yogyakarta septi.riana@staff.uty.ac.id

\begin{tabular}{l}
\hline Info Artikel \\
\hline Sejarah Artikel: \\
Diterima 3 Mei 2019 \\
Direvisi 27 Mei 2019 \\
Disetujui 29 Mei 2019 \\
\hline
\end{tabular}

Keywords:
WhatsApp, Implementation,
Integrated English, students'
responses

\section{Abstract}

This study aimed to illustrate some learning activities in Integrated English class by utilizing WhatsApp application and how the students respond to its implementation. The study was conducted in Accounting Department at University of Technology Yogyakarta. The subject of this study was 66 students in Accounting Class A of 2018/2019 Academic Year. The instruments to gather the data were observation, questionnaires and unstructrured interview. The result of this study showed that WhatsApp Application could be utilized as one of the beneficial devices to assist students in learning integrated English and there were positive responses from students during the implementation of WhatsApp in their learning process.

\begin{abstract}
Abstrak
Penelitian ini bertujuan untuk menggambarkan kegiatan pembelajaran di kelas Integrated English dengan memanfaatan aplikasi WhatsApp dalam mata kuliah Integrated English dan bagaimana siswa merespon penerapannya. Penelitian dilaksanakan di Prodi Akuntansi di Universitas Teknologi Yogyakarta. Subjek penelitian ini adalah 66 mahasiswa di kelas Akuntansi A pada semester gasal tahun akademik 2018/2019. Instrumen yang digunkan untuk mengumpulkan data adalah observasi, kuesioner, dan wawancara tidak terstruktur. Hasil penelitian ini menunjukkan bahwa Aplikasi WhatsApp dapat digunakan sebagai salah satu perangkat yang bermanfaat untuk membantu siswa dalam kelas Integrated English dan terdapat tanggapan yang positif dari mahasiswa selama penerapan WhatsApp dalam proses pembelajaran mereka.
\end{abstract}


Dewi, Septi Riana

UTILIZING WHATSAPP APPLICATION FOR TEACHING INTEGRATED ENGLISH ...

REFLEKSI EDUKATIKA : Jurnal Ilmiah Kependidikan, Volume 9, Nomor 2, Juni 2019, hlm 164-171

\section{INTRODUCTION}

Teaching a large class can present many challenges, both in and out of the classroom. In the classroom, large enrollments can promote student disengagement and feelings of alienation, which can gradually decrease students' sense of responsibility and lead to behaviors that both reflect and promote lack of engament.

Most teachers agree that teaching a small class is easier, exciting, and less time and energy consuming than teaching a large one. Unfortunately, since there are some barriers in the matter of budgets, space, or lack of teacher, many educational institutions offer large class in conducting English Foreign Language class.

For teachers, their classes are larger than they would like them to be. Large classes can present a number of challenges that teachers of small classes are less likely to face. What we label a" large class" depends mostly on context and expectations. Some teachers in private school may expect 10 to 15 students in their class, for them having 20 students is often seen as too large. Yet for many primary and secondary teachers around the world who teach 30 or 40 students, a class of 20 would be a welcome relief. It goes in line with Hayes cited on Qiang \& Ning (2011) thinks the ideal size of language class is 30 at most because only under such a scale can offer enough chances for students to communicate with each other.

Dealing with large class, there is no reason for teachers of giving up and not improving their teaching techniques. Teacher could see large classes as challenges and when they achieve their goal in improving the quality of of students' learning progress, it will bring great satisfactions of all teachers. Many experienced teachers can teach 20 students effectively, but when you do it with 50 or more you know you have really accomplished something.

In university level, teaching in large class is not a suprising phenomenon. Large classes commonly occur in general university courses (MKU). In University of Technology Yogyakrta, one of MKU is English subject which has been taken by all students from different departments in university. English subject has two levels conducted in the first and second semester; Integrated English and Communicative English. Those courses are offered in the first and second semester.
In Accounting Department, Integrated English is an English subject taken in the first semester. From the observation, the teaching learning process of Integrated English class has been running well, but when it seems not comfortable enough seeing 66 students joining together in one class. Most of students in Integrated English Class A were very inseparable by their mobile phones. They did a lot of activities such as taking pictures, texting, watching videos, playing on line game (Mobile Legend and PUBG), or just browsing the internet. This condition sometimes distracts their concentration in learning in traditional way. It also gets worsen when students sitting in the back seats make such noise or fall asleep while teacher is teaching.

Considering the condition above, the teacher was encouraged to incorporate students' mobile phone as a part of learning media in Integrated English class. Maximizing the use of their mobile phone especially WhatsApp Application can help students to feel excited during the teaching learning process. More importantly, as WhatsApp is one of mobile application which is closely related to the time and their need in interest, it can hide their barriers or anxiety that can affect their learning achievement, such as feeling afraid of making mistake or embarrassed to speak in front of the class.

As one of the popular mobile application, WhatsApp provides many features that allow students and teacher to have interaction online. Teacher can set a WhatsApp group to facilitate students in discussion, putting some online materials, conducting quiz, recording, and many more. Those activities can be arranged by the teacher to improve students' skills. Therefore, this paper attempts to study on how WhatsApp application is used in teaching Integrated English and to find out students' response on the use of WhatsApp as their learning media.

There are many studies that have been conducted by several researchers using WhatsApp in ELT. They used WhatsApp for teaching English language skills. Those studies brought evidences that WhatsApp is one of the best mobile application for teaching English. Fattah (2015) conducted a study entitled the Effectiveness of Using WhatsApp Messenger as One of Mobile Learning Techniques to Develop Students' Writing Skills. The result of the study 
showed that WhatsApp could give significant effects on students' writing skills of English Department at private university in Saudi Arabia. Another study conducted by Justina (2016), she used WhatsApp to enhance reading and writing skills at undergraduate college level in Osmania University India. The result of her study showed that the use of WhatsApp was very essential for language teachers to identify what their students enjoy and utilize it to engage them in language development, especially reading and writing which slow learners find difficulty when it was conducted in the conventional way. Furthermore, Kheryadi (2017) conducted a study by implementing WhatsApp as a media of English language teaching by distributing some questions to subject of his study. The result revealed that the students felt confident, independent, enthusiasm, and had a positive attitude to learn English using WhatsApp application. Compared to the previous studies, this study will try to provide some activities for listening, speaking, reading and writing in English language teaching (integrated English class).

\section{RESEARCH METHOD}

In order to answer the research questions, this employed a mixed method approach to put quantitative and qualitative data togeteher. The paradigm of the research involves the collection and analysis of quantitative and qualitative data to provide better understanding in answering research questions investigated in the study (Malik\&Hamied, 2016). It is in line with Cresswell (2009) who stated that mixed methods utilize the strength of both qualitative and quantitative research. The study adopted the concurrent triangulation design which allowed the researcher to collect both quantitative and qualitative data concurrently and to compare the data to figure out if there is convergence, differences, or some combination (Cresswell, 2009).

The research was conducted in the odd semester. It started from 1 October 2018 and ended on 13 January 2019. There was one Integrated English class taken as subject of the research. It was from Accounting Department of University of Technology Yogyakarta. There were about 66 students who enrolled this course. The writer used WhatsApp as learning media in teaching Integrated English. The writer gathered the data from the class through observations, interview, and questionnaire.

\section{FINDING AND DISCUSSION \\ The Use of WhatsApp in Integrated English Class}

According to Wilson \& Bolliger cited in Ibrahim (2018) stated that principally mobile learning aims to faciliate the learners in learning whenever and wherever they can since it can be accesed everywhere by providing an access for all various learning materials. The followings are the procedure of utilizing WhatsApp as mobile learning media and the implementation WhatsApp in Integrated English class.

A. Procedure of Utilizing WhatsApp in Teaching English

Before conducting English class trough WhatsApp, there are some steps must be followed by the teacher. The steps are adapted from Sprefoff (2016) with some modification. The steps are as follows;

Step 1. Create a WhatsApp Group

Teacher divides the class into 3 WA groups. Each WA group consists of 22 students. It aims to ease the teacher in controlling the activities in each WA group.

Step 2. Set the rules

Teacher sets some regulations dealing the use of WA. They are; the students must use language politely, they are not allowed to share any information out of the topic discussed, and they are allowed to use informal chats in English. Step. Set up for class use

Teacher can set the activities related to the topics discussed in students' handout and course syllaby.

Step 4. Assign the tasks

Students will have various assignments in four skills; listening, speaking, reading and writing. Those tasks are given to provide additional opportunity to improve their performance.

B. The Implementation of WhatsApp Application in Integrated English Class

According to syllable of Integrated English course, there are 12 topics discussed for one semester. The topics are integrated into 4 skills; listening, speaking, reading and writing. The followings will be presented the topics division with the skills in online EFL activities using WhatsApp mobile features. 
Dewi, Septi Riana

UTILIZING WHATSAPP APPLICATION FOR TEACHING INTEGRATED ENGLISH ...

REFLEKSI EDUKATIKA : Jurnal Ilmiah Kependidikan, Volume 9, Nomor 2, Juni 2019, hlm 164-171

\section{Listening}

Listening is a passive skill and improving listening skills in a second language is not easy since students have to process both content knowledge and linguistics knowledge simultaneously while listening. Listening can be defined as "identifying the sounds of speech and processing them into words and sentences". One of the aims to teach English listening is to prepare students for understanding actual speech in real communication situations. Huang and Sun (2010) cited on Gangaimaran \& Pasupathi designed a system to use mobile devices for listening. They constructed a website which uploaded learning materials including video, and few listening exercises. They studied the capability of mobile technology on English listening skills and concluded that mobile English listening exercise system made students develop English listening abilities to higher degree. In line with Huang and Sun, WhatsApp is also mobile device that can provide uploaded material and exercises for listening skill.

To enhance the students' listening skill, the writer chooses 2 topics from Integrated English module to be developed into online activity. The following are the activities:

1.1 First listening activity conducted through WhatsApp was taken from unit 2 with the topic "It's a beautiful day". The activity is named "Change 3 words". The teacher chooses a short text from the Integrated English module. The teacher films the text and reads it at the same time, but instead of reading the exactly as it is written, the teacher changes three words in some parts of the text. The students need to watch and listen to what the teacher said in order to identify which words were changed. The students reply in audio or text with the words that were changed.

1.2 Second listening activity conducted through WhatsApp was taken from unit 5 with the topic of daily activity. We can call the activity as "Audio Diary". Students record what they are doing at different times of the day. They can compare and see how similar or different their days are.

\section{Speaking}

Speaking is always considered as the most difficult skill since it requires the learners to think and speak at the same time. Pourgharib \& Salamat (2013) conducted a study to improve the speaking knowledge of EFL students on using mobile phones. There were 40 students including males and females up to 18 years old and with average age of 25 participated in their study. The participant both experimental and control groups were provided with an opportunity to review and recycle English drills about speaking. In every session, the participant in the experimental group talk on their mobile phones in English. Participant in the control group, however, received no extra treatment at all. The result showed that the participant who had benefited from mobile-assisted learning had a significantly better performance on a speaking posttest than the participants in the control group.

Regarding the previous studies, WhatsApp can also present mobile-assisted learning since WhatsApp application provides features for learning speaking. There are 2 features on WhatsApp that can we use in speaking activities like video and audio. In this case, the operation of speaking activity is conducted as follows:

\subsection{Guided Conversation}

Guided conversation is the conversation that occurs under the teacher's guidance. The teacher actively take part in an online dialogue. The first activity of dependent conversation is taken from unit 1 with the topic of Introduction and personal information in which students must respond teacher questions. Teacher puts "Distant Interview" as the activity of dependent conversation. One student records question that they want to ask their classmates. They send these one at a time. The other student records and sends the answers. Teacher role here is giving feedback to the students' answers on lexis and grammar.

\subsection{Independent Conversation}

Independent conversation is carried out without teacher involvement. It allows students to communicate among them to discuss any ideas they want to talk about. In this model, students have chance to build conversations on free topics to maintain their interpersonal communication. Teacher plays important role in facilitating a WhatsApp group, motivating students to express their personal feelings, and monitoring the students' participation to observe whether they are active or not during the online conversation. Teacher is not directly involved in the conversation to encourage students' confidence 
and experience informal situation. In this case, teacher create an activity namely "Tour Guide". Students make a short video in two-three minutes duration. The video is about a place they know well. This could be their house, café, park, etc. They could be either give the commentary as they film, or one student could be the presenter, while other does filming.

\section{Reading}

Reading is another passive skill besides listening. It provides common source to achieve and develop student's knowledge to improve their ability in accessing the world information which commonly provided by digital and electronic media and printed materials. Astarila (p.28) stated that mobile learning has role in enhancing contextual and authentic learning practices on reading comprehension. It can enhance students by connecting the content of lesson into real life. It also helps the student to understand the topic discussed easier. According to Kukulska et. Al (2009) cited on Liva Astarila mobile learning provided EFL students with substantial contextual opportunities that extended outside the classroom. It is not only stimulated collaboration and interaction between students, but also enhanced their context awareness about their surrounding environment.

In boosting student enthusiasm in reading skill, the teacher sends a simple reading text. The selection of reading material is based on the grammar focus of simple present and simple past tense that available on their module. The text provided by teacher is beneficial to give students exercises for improving their vocabulary and reading comprehension. The reading activities are carried by the followings:

\subsection{Read and Answer True or False Questions}

In the first reading activity, teacher provides a text entitled "Nuclear vs Extended Family". Students are required to read the text and answer questions related to the text. The reading exercises are provided in True or False model. Students are asked to answer the questions using emoji. The emoji used in this activity could be thumb up or smile for True answer and thumb down or cry for False answer.

\subsection{Rebus Reading}

In this activity, teacher provides a text which combines pictures to represent words. The reading topic is taken from unit 10 of the Integrated English module. The text is entitled "Jack and The Bean Stalk". Teacher rewrite the text which by combining pictures to replace some words in different lines and paragraph. Then students practice using the words they know. Students are asked to complete a text with many missing words on each line or paragraph.

\section{Writing}

Exploring the use of WhatsApp for teaching and learning writing is also interesting. Writing is a complex skill compared to other three skills in English learning. EFL learning institutions are recently attracted to use WhatsApp as an instructional tool to develop student's language skills and motivation. Fattah (2016) conducted a study on the use of WhatsApp messenger to develop students' writing skills. The finding of his study reported that there's significant improvement on the student writing quality. The students felt free to express their ideas and felt happy to correct and edit their peer works.

Assisting students to develop their writing skills, teacher can create varied writing activities in WhatsApp group. In this stage, teacher employs two main activities; sentence writing and text writing. Teacher focuses on giving students to write sentences/paragraph using simple present and simple past tense. The features used in this activity are emoji, photo and text. The learning model of writing is as follows:

\subsection{Writing questions and statements using Emoji.}

Providing different writing activity is one of the teacher's target in this case. Teacher asks students to choose five emoji and send these emoji to their classmates. The second student/ assigned student needs to write questions or statements that contains all five of the words/concepts that correspond to the Emoji.

\subsection{Writing Narrative Text}

In this activity, WhatsApp features we use are photo and text. Teacher names the activity as "Photo Story". Students take a series of five or six photos that tell a story. Students are asked to write the narration for each photo as a caption.

\section{Students' Perception \\ a. Questionnaire \\ The questionnaire was implemented to get responses from all students who joined}


Dewi, Septi Riana

UTILIZING WHATSAPP APPLICATION FOR TEACHING INTEGRATED ENGLISH ...

REFLEKSI EDUKATIKA : Jurnal Ilmiah Kependidikan, Volume 9, Nomor 2, Juni 2019, hlm 164-171

WhatsApp group of Integrated English in class A of Accounting Department. There were 66 students who filled in the questionnaires. The questionnaires were dealt with the opportunities provided by WhatsApp group learning.

\begin{tabular}{|c|c|c|c|c|c|c|c|}
\hline No & Statement & SDA & DA & $\mathbf{N}$ & $\mathbf{A}$ & $\mathbf{S A}$ & $\begin{array}{c}\text { Total } \\
\text { frequency } \\
(\text { total } \%)\end{array}$ \\
\hline 1 & $\begin{array}{l}\text { WA assisted me to get } \\
\text { boarder understanding } \\
\text { of topics discussed in } \\
\text { class. }\end{array}$ & 0 & 0 & $\begin{array}{c}10 \\
(15 \%)\end{array}$ & $\begin{array}{c}19 \\
(29 \%)\end{array}$ & $\begin{array}{c}37 \\
(56 \%)\end{array}$ & $\begin{array}{c}66 \\
(100 \%)\end{array}$ \\
\hline 2 & $\begin{array}{l}\text { WA helped me to deal } \\
\text { with my fear in using } \\
\text { English. }\end{array}$ & 0 & 0 & $\begin{array}{c}4 \\
(6 \%)\end{array}$ & $\begin{array}{c}34 \\
(51.5 \%)\end{array}$ & $\begin{array}{c}28 \\
(42 \%)\end{array}$ & $\begin{array}{c}66 \\
(100 \%)\end{array}$ \\
\hline 3 & $\begin{array}{l}\text { WA helped me to } \\
\text { improve my listening } \\
\text { skill. }\end{array}$ & 0 & 0 & $\begin{array}{c}15 \\
(23 \%)\end{array}$ & $\begin{array}{c}25 \\
(38 \%)\end{array}$ & $\begin{array}{c}26 \\
(39 \%)\end{array}$ & $\begin{array}{c}66 \\
(100 \%))\end{array}$ \\
\hline 4 & $\begin{array}{l}\text { WA helped me to } \\
\text { improve my English } \\
\text { vocabulary. }\end{array}$ & 0 & 0 & $\begin{array}{c}6 \\
(9.1 \%)\end{array}$ & $\begin{array}{c}27 \\
(40.9 \%)\end{array}$ & $\begin{array}{c}33 \\
(50 \%)\end{array}$ & $\begin{array}{c}66 \\
(100 \%)\end{array}$ \\
\hline 5 & $\begin{array}{l}\text { WA helped me to } \\
\text { improve my speaking } \\
\text { skill. }\end{array}$ & 0 & 0 & $\begin{array}{c}11 \\
(17 \%)\end{array}$ & $\begin{array}{c}26 \\
(39 \%)\end{array}$ & $\begin{array}{c}29 \\
(44 \%)\end{array}$ & $\begin{array}{c}66 \\
(100 \%)\end{array}$ \\
\hline 6 & $\begin{array}{l}\text { WA helped me to } \\
\text { improve my reading } \\
\text { skill. }\end{array}$ & 0 & 0 & $\begin{array}{c}7 \\
(11 \%)\end{array}$ & $\begin{array}{c}39 \\
(59 \%)\end{array}$ & $\begin{array}{c}20 \\
(30 \%)\end{array}$ & $\begin{array}{c}66 \\
(100 \%)\end{array}$ \\
\hline 7 & $\begin{array}{l}\text { WA helped me to } \\
\text { improve my writing } \\
\text { skill. }\end{array}$ & 0 & 0 & $\begin{array}{c}13 \\
(20 \%)\end{array}$ & $\begin{array}{c}32 \\
(48 \%)\end{array}$ & $\begin{array}{c}21 \\
(32 \%)\end{array}$ & $\begin{array}{c}66 \\
(100 \%)\end{array}$ \\
\hline 8 & $\begin{array}{l}\text { Participating in } \\
\text { English WA group } \\
\text { helped boosting my } \\
\text { interaction in English } \\
\text { than when I would not } \\
\text { participate }\end{array}$ & 0 & 0 & 0 & $\begin{array}{c}19 \\
(29 \%)\end{array}$ & $\begin{array}{c}47 \\
(71 \%)\end{array}$ & $\begin{array}{c}66 \\
(100 \%)\end{array}$ \\
\hline 9 & $\begin{array}{l}\text { WA helped me to } \\
\text { know my } \\
\text { errors/mistakes } \\
\text { through error analysis } \\
\text { and editing of other } \\
\text { students }\end{array}$ & 0 & 0 & $\begin{array}{c}13 \\
(20 \%)\end{array}$ & $\begin{array}{c}25 \\
(38 \%)\end{array}$ & $\begin{array}{c}28 \\
(42 \%)\end{array}$ & $\begin{array}{c}66 \\
(100 \%)\end{array}$ \\
\hline 10 & $\begin{array}{l}\text { WA motivated me to } \\
\text { learn English }\end{array}$ & 0 & 0 & $\begin{array}{c}3 \\
(5 \%) \\
\end{array}$ & $\begin{array}{c}30 \\
(45 \%)\end{array}$ & $\begin{array}{c}33 \\
(50 \%) \\
\end{array}$ & $\begin{array}{c}66 \\
(100 \%) \\
\end{array}$ \\
\hline
\end{tabular}

The result showed that there were no "disagree" or "strongly" disagree responses to the statements. To respond to the first statement, 37 students strongly agreed, 19 students agreed, and 10 neither agreed nor disagreed (neutral). To respond to the second statement, 28 students strongly agreed, 34 students agreed, and 4 was neutral. In the third statement, there were 26 "strongly agree" responses, 25" agree" responses, and 15" neutral" responses. The fourth statement was responded with 33 "strongly agree" responses, 27 "agree" responses, and 6 "neutral" responses. To respond to the fifth statement, 29 students 
strongly agrred, 26 students agreed, and 11 students were neutral. To respond to the sixth statement, 20 students strongly agreed, 39 students agreed, and 7 students were neutral. The seventh statement got 21 "strongly agree" responses, 32 "agree" responses, and 13" neutral" responses. The eight statement was responded with 47 "strongly agree" responses and 19 "agree" responses. To respond to the ninth statement, 28 students strongly agreed, 25 students agreed, and 13 students were neutral. The last question was responded with 33 "strongly agree" responses and 30 "agree" responses, and 3 "neutral" responses.

From the result of questionnaire above, it can be said that most of students have positive responses toward the use of WhatsApp application in their learning process.

\section{b. Student Interview}

There were 10 students chosen randomly to be interviewed. Their answers were almost similar in every question. Here is the summary of the students answer to the questions in the interview:

1. Did you spend a lot of Internet quota to join activity in WA group?

All of the students answered that they did not spend a lot of Internet quota.

2. Was it easy to access the material and task given through WA group?

All of the students stated that it was accessible, and they did not find any difficulties to complete the task given by the instructor.

3. Did WA group activity ease the way of the students in learning English?

All of the students agreed that WA made their learning process easier than traditional one conducted in the class.

4. Did you find the various activities conducted through WA group were attractive?

Seven students answered that the activities were attractive since they were assigned to use emoticon or emoji and some photos.

Three students said that the part of making short video was the most attractive activity.

5. Were your assignments technically easy to do?

All of the students said that it was easy to work with the assignment.
6. Was it advantage for you when you get direct feedback from your instructor?

All of the students answered that they could figure out their mistakes and learn from the mistakes directly.

7. Did you like to do activities through your WA group?

All of the students enjoyed the activities conducted through WA group.

8. State your opinion about WA group as a medium for learning English?

All of the students stated that WA was interesting and easy to be done.

\section{CONCLUSION}

Teaching English in a large class is very challenging. It forces teachers to be creative in providing attractive activities to engage the students in the learning process. The existence of learning tool also plays an important role to help teachers in assisting the teaching learning process. Applying WhatsApp in integrated English class gives a lot of chances on how to assist students learning English optimally. In general, utilizing WA does not only provide interest for student to learn, but it also creates a wide opportunity to practice English regularly without being restricted by the time and course meeting. The features of WhatsApp: emoji, picture, audio, links, document, create groups, and text could be utilized optimally in Integrated English class and during the implementation of WAG learning activities, students presented positive responses.

\section{REFFERENCES}

Astarilla, L \& Warman D. 2017. The Effect of WhatsApp in Blended Learning on English as Foreign Language (EFL) Undergradutae Student's Reading Comprehension. Advances in Social Sciences, Education and Humanities Research. 110, 74-77.

Cresswell, J.W. 2009. Research design: Qualitative, Quantitative, and Mix Methods Approaches. Thousand Oaks, California: SAGE Publications, Inc.

Fattah, S. F. E. S. A. 2015. The Effectiveness of Using WhatsApp Messenger as One of 
Dewi, Septi Riana

UTILIZING WHATSAPP APPLICATION FOR TEACHING INTEGRATED ENGLISH ...

REFLEKSI EDUKATIKA : Jurnal Ilmiah Kependidikan, Volume 9, Nomor 2, Juni 2019, hlm 164-171

Mobile Learning Techniques to Develop Students' Writing Skills. Journal of Education and Practice. 6 (32), 115-127.

Gangaiamaran, R. \& Pasupathi, M. 2017. Review on Use of Mobile Apps for Language Learning. International Journal of Applied Engineering Research. 12 (21): 11242-11251.

Ibrahim, N \& Ishartiwi. 2017. Pengembangan Media Pembelajaran Mobile Learning Berbasis Andoroid Mata Pelajaran IPA untuk Siswa SMP. Jurnal Refleksi Edukatika. 8 (1): 80-89.

Justina, M. 2016. Use of WhatsApp to Enhance Reading and Writing skills at Undergraduate College Level. Journal of Language in India. 16: 47-60.

Kheryadi. 2017. The Implementation of WhatsApp as A Media of English Language Teaching. LOQUEN. 10 (2): 114.

Kukulska-Hulme, A\& Shield, L. 2008. An Overview of Mobile Assisted Language
Learning: from Content Delivery to Supported Collaboration and Education. ReCALL. 20: 271-289.

Malik, R.S. \& Hamied, F.A. 2016. Research Methods: A Guide for First Time Researchers. Bandung: UPI Press.

Pourgharib \& Salamat. 2013. The Effect of Using Mobile Application on EFL Students Speaking. International Research Journal of Applied and Basic Sciences. 4 (11): 3526-3530.

Qiang, W \& Ning, Z.2011. Teaching Large Classes in China- English as a Foreign Language. China: Beijing Normal University.

Sperrof, Y. 2016. Using WhatsApp for Speaking and Listening Practice (paper presented on TESOL Greece $37^{\text {th }}$ Annual Convention 2016 in Athens, Greece). Retrived on September 30, 2018 from https://yulivaperoffblog.wordpress.com/2 016/09/11/using-whatsapp-for-speakingand-listening-practice/. 